\title{
THE INFLUENCE OF ACCUMULATIVE PENSION PROGRAMMES ON THE EFFICIENCY OF THE FUNCTIONING OF NATIONAL PENSION SYSTEMS OF THE EASTERN EUROPEAN COUNTRIES AND UKRAINE
}

\author{
Svitlana Burdeniuk ${ }^{1}$
}

\begin{abstract}
The aim of the scientific article is to study the peculiarities of the operation of funded pension systems in Eastern Europe, determine their advantages, disadvantages, the impact of various factors on their efficiency, assess the role of funded pension insurance in them and to justify their positive experience in pension reform of Ukraine. Research methods. When writing a scientific article, appropriate research methods were used: balance, monograph methods, the method of statistical grouping and tables, methods of analysis using generalizing indicators: absolute and relative, averages and time series data. Research methodology. The assessment of the level of social standards of pension systems in Eastern Europe and Ukraine was carried out by comparing the level of pensions, wages, replacement rate. The demographic situation was characterized by the use of forecast calculations of international financial organizations. The information and methodological base of the research was the materials of international financial organizations, which characterize the development of funded pension systems in Eastern Europe, forecast calculations in the demographic sphere, special economic literature, scientific works of domestic and foreign scientists on the study of funded pension insurance. Results. The scientific article considers the issues of reforming the national pension systems of Eastern Europe in modern conditions, the peculiarities of their development taking into account the manifestation of demographic factors, focuses on the functioning of multilevel pension models, defines the role of funded pension programmes in pension income. It is noted that modern approaches to the formation of national pension systems are based on the use of pension insurance principles. An assessment of the level of social standards in Eastern Europe is made and a comparative analysis of them with the relevant indicators in Ukraine is given, the features of the use of funded pension programmes at the present stage of reforming the pension systems of Eastern Europe are identified. The necessity and preconditions of introduction of obligatory accumulative pension insurance in Ukraine at the present stage of reforming its national pension system are substantiated, it is noted that practical use of accumulative pension programmes will gradually lead to increase of social protection level of people of retirement age, increasing investment in the national economy.
\end{abstract}

Key words: accumulative pension insurance, replacement coefficient, national pension system, accumulative pension programmes, minimum pension, social standards, criteria of efficiency of pension systems functioning.

JEL Classification: G23, H53, H55, G22, 138

\section{Introduction}

The European choice of Ukraine means a consistent focus on the acting model of socially oriented economy in the leading European countries. The advantages of this model are a high level of social standards, effective protection of workers' rights, and developed system of social protection. The approximation to economic and social standards of the European Union requires fulfillment of a number of conditions stipulated by the agreements between Ukraine and the European Union.

Citizens' pensions are one of the most important components of a socially oriented economy. The existence of guaranteed pension rights for Ukrainian citizens should be considered as an

\footnotetext{
Corresponding author:

${ }^{1}$ SSU "Kamianets-Podilskyi Professional College of Food Industry,

National University of Food Technologies”, Ukraine;

Podilsky Special Education and Rehabilitation Socio-Economic College, Ukraine.

E-mail: burdenyuklana@gmail.com

ORCID: https://orcid.org/0000-0002-0749-4985
} 
expression of the level of civilized development of the state and its humane maturity. As a result, the role of the national pension system is growing, and its model is in line with the needs of citizens of retirement age. Modern approaches to the formation of national pension systems are based on the use of pension insurance principles. Most countries use multi-level pension models with redistributive and funded pension schemes.

As the experience of reforming the pension systems of European countries shows, the role of funded pension programs has been growing in recent years. This is due to the fact that the joint redistributive pension system, due to the influence of relevant factors, can no longer provide a sufficiently high level of income for retirees. This encourages the governments of many countries to seek additional financial resources to address this problem. They find those resources in the use of accumulative pension programmes, on which the functioning of the second and third levels of national pension systems is based. This leads to increased scientific interest in studying the peculiarities of the development of funded pension insurance and its use in the pension sector.

It is important for our country to study the experience of implementing the use of funded pension programmes in Eastern Europe, which also build multi-level national pension models based on the principles of pension insurance. Like Ukraine, they went through the stages of reforming their national economy in market conditions and solved many issues that now need to be addressed by our state.

The purpose of the work is to study the peculiarities of the operation of funded pension systems in Eastern Europe, identify their advantages, disadvantages, the impact of various factors on their effectiveness, assess the role of funded pension insurance in them and justify their positive experience in reforming the pension system of Ukraine on this basis.

Research methodology. When writing a scientific article, various research methods were used, such as balance, monograph methods, the method of statistical grouping and tables, methods of analysis using generalizing indicators: absolute and relative, average values and indicators of a number of dynamics. The information and methodological base of the research included the materials of international financial organizations, which characterized the development of funded pension systems in Eastern Europe, forecast calculations in the demographic sphere, special economic literature, scientific works of domestic and foreign scientists on the study of funded pension insurance. Relevant legal documents related to the formation and reform of the national pension system of Ukraine, websites of the Main Department of the Pension Fund of Ukraine were also used.

\section{The impact of the demographic situation on the reform of national pension systems}

One of the main factors that accelerated the process of reforming the pension systems of most countries were the processes in the demographic sphere of society. According to international financial organizations, the world is aging, which is manifested in the increasing share of older people in the age structure of the population. According to international experts, the aging process is becoming one of the most significant social transformations of the 21 st century, the impact of which affects almost all spheres of social development. Current demographic indicators and projections show the growing scale and dynamics of aging in the world as a whole, and in Europe in particular.

Forecasts by international financial institutions show that low birth rates and declining mortality have led to accelerated planetary "aging" since the 1980 s, and that the world population aged 65 and over is expected to increase by 2.6 times - up to 1.6 billion people, and its share - respectively, almost by 2 times - 16\% in 2015-2050 (Changing population age structures and sustainable development, 2017).

If we analyse the demographic situation by region, the worst forecasts are expected for Europe. It is expected that the share of elderly people in this region will increase from $17.6 \%$ in 2015 to 27.6 in 2050, which will characterize Europe as the "oldest" region in the world.

Demographers consider declining birth rates, reducing mortality and increasing life expectancy to be the main factors of population aging. In addition, for the countries of Eastern Europe, the trends that lead to population decline are the peculiarity of the demographic sphere in modern conditions and in the nearest future. According to experts in the field of pensions, the biggest problems with social protection of citizens of retirement age arise and will continue to worsen in those countries where the population is both aging and shrinking (When should the state pension age increase to 66). 
Table 1

Countries with the highest rates of population decline in 2015-2050

\begin{tabular}{|c|c|c|c|c|c|}
\hline \multirow{2}{*}{$\begin{array}{l}\text { № } \\
\mathrm{s} / \mathrm{n}\end{array}$} & \multirow{2}{*}{ Countries } & \multicolumn{2}{|c|}{ Sequence number, thousands of people } & \multicolumn{2}{|c|}{ Change in numbers } \\
\hline & & 2015 & 2050 & thousands of people & $\%$ \\
\hline 1. & Bulgaria & 7150 & 5154 & -1996 & -27.9 \\
\hline 2. & Romania & 19511 & 15207 & -4304 & -22.1 \\
\hline 3. & Ukraine & 44824 & 35117 & -9707 & -21.7 \\
\hline 5. & Bosnia and Herzegovina & 3810 & 3069 & -741 & -19.4 \\
\hline 6. & Latvia & 1971 & 1593 & -378 & -19.2 \\
\hline 7. & Lithuania & 2878 & 2375 & -503 & -17.5 \\
\hline 8. & Serbia & 8851 & 7331 & -1520 & -17.2 \\
\hline 9. & Croatia & 4240 & 3554 & -686 & -16.2 \\
\hline 10. & Hungary & 9855 & 8318 & -1537 & -15.6 \\
\hline 13. & Poland & 38612 & 33136 & -5476 & -14.2 \\
\hline 14. & Estonia & 1313 & 1129 & -184 & -14.0 \\
\hline
\end{tabular}

Source: World Population Prospects, 2015

The post-socialist states of Eastern Europe (including Ukraine) are currently facing a rapid decline in the population against the background of a fairly high level of aging in Europe (Table 1). Compared to Western European and Scandinavian countries, they currently have and are projected to have much higher rates of population decline in the future. According to international financial organizations and leading scientists, these countries are Bulgaria, Romania, and Ukraine.

By 2050, the number of citizens in these countries is estimated to decrease by $27.9 \%, 22.1 \%$, $21.7 \%$, respectively. Therefore, this situation in the demographic sphere does not contribute to raising social standards for citizens of retirement age in our country.

The demographic crisis affects the need to improve national pension systems, find new sources of funding in order to maintain the level of income of citizens of retirement age at the appropriate level. According to experts in the field of pensions, in the coming decades for almost all countries of the world the problems of providing social support for the elderly and the sustainability of pension systems will become extremely important. This is due to the fact that the integral typical principles of modern pension systems are the solidarity of generations and social orientation, which complement the evolution, multilevel construction, institutional certainty, universality and voluntariness of pension rights, the priority of social insurance (Mikhalkina, Pysanka, 2013).

\section{Assessment of the level of social standards in Eastern Europe and Ukraine}

Studies show that most Eastern European countries began to use the mandatory funded pension system at the end of the last century the beginning of this century. It should be noted that each country can boast of the peculiarities of its pension system, as the mechanism of its formation and functioning depends on the peculiarities of national legislation, the demographic and economic situation, the development of financial markets.

Poland was one of the first countries in Eastern Europe to introduce a mandatory funded pension system. Under its national law, all able-bodied people under the age of 30 have been required to participate in funded pension schemes since 1999. All three levels of the Polish pension system complement and reinsure each other.

The Czech Republic uses a multilevel model of forming its national pension system. But, unlike Poland, it uses slightly different ways to solve the financial problems of its citizens' pensions. The national pension system in the Czech Republic maintains a mandatory state pension scheme in a reformed form based on distributive principles. The second component is a voluntary system based on private pension insurance. In recent years, the number of participants in private pension insurance who pay insurance contributions to private pension funds has increased.

Accumulative pension systems, formed on the principles of pension insurance, began to be 
introduced at the beginning of the 21st century in Bulgaria, Slovakia, Croatia, Romania, Slovenia, and Macedonia.

The global economic crisis has made its adjustments to the further introduction of mandatory funded pension insurance in Eastern Europe. The situation has changed towards the curtailment or partial freezing of funded pension programmes in some countries. State pension systems have begun to be revalued. Pension assets at the second level, as a result of various financial risks, did not reach the projected value, which affected the size of pension benefits (The World Bank, 2013).

In the post-crisis period, Eastern European countries continued to reform their national pension systems. The directions and strategy of pension reforms are reflected in the relevant legislative documents of the European Union. In April 2017, the European Commission adopted a legal document that defines the relevant principles and rights regarding the income and pension provision of the elderly, according to which the reform of the pension provision in the EU should be carried out. This document is called "European pillar of social rights" (HelpAge International, 2015). It aims to provide guarantees of a decent standard of living for all older people, as well as to acquire pension rights for employees and the selfemployed persons.

In connection with such decisions of the European financial institutions and the relevant regulations adopted for the further reform of national pension systems, it can be argued that their second and third levels are given considerable attention. This means that funded pension schemes, both mandatory and voluntary, have practical application and continue to play an extremely important role in increasing citizens' retirement incomes.

The use of multi-level pension systems by Eastern European countries contributes to a gradual increase in the pension incomes of their citizens. This is evidenced by the assessment of the level of social security and welfare of people of retirement age in Eastern European countries and its comparison with the relevant indicators of Ukraine, made by experts of the Razumkov Centre (Pishchulina, Koval, Burlai, 2017). They conducted it using the Global Index of Quality of Life and Welfare of the Elderly. Since 2013, it has been defined by the international non-governmental organization "HelpAge International" together with the United Nations Population Fund (HelpAge International, 2015). In scientific circles this complex indicator is also called the index of efficiency of pension systems because of its important role in ensuring the welfare of retirement age citizens (Pishchulina, Koval, Burlai, 2017).

According to the results of such an assessment among Eastern European countries in 2015, the rating of quality of life and well-being of the elderly is the highest in the Czech Republic, Estonia is in second place, and Slovenia is in third place (Table 2). It is noteworthy that the fourth indicator in this rating is Georgia, which is ahead of many Eastern European countries. It also should be mentioned that the Czech Republic is among the twenty countries in the world with the highest global figure. For Ukraine, this figure is quite low, and in the world ranking, it took only 73rd place in 2015 (Table 2). The lowest rates among European countries are only in Moldova (77th place) and Greece (79th). This indicates that Ukrainian pension system today is not sufficiently developed and effective, thus not providing them with a decent standard of living, proper social standards and opportunities for social realization.

The low level of social standards in Ukraine is confirmed by studies comparing pensions and wages in European countries (Table 3). To assess these indicators, the countries representing Eastern Europe - Poland and Western Europe - Germany were taken.

In Poland, which together with other Eastern European countries has become a member of the European Union and is completely restructuring its national economy on the principles of a market economy, the minimum pension in 2020 was 242.8 EUR. This figure is almost twice lower than in Germany, and the average pension is almost 3.5 times lower. This tendency is observed in subsequent years. This shows that even the countries of Eastern Europe, which have been members of the EU for a long time, have not yet reached the level of economic development and social protection of their citizens in comparison with Western European countries.

Analysing social standards in Ukraine, it should be noted that they are much lower than in Poland, and Western European ones in general are many times higher than Ukrainian indicators. Thus, the minimum pension in 2020 in Ukraine 
Table 2

Rating of quality of life and well-being of elderly people in Eastern Europe and Ukraine (2015)

\begin{tabular}{|c|c|c|c|c|c|c|c|c|c|c|}
\hline \multirow{2}{*}{ Countries } & \multicolumn{2}{|c|}{ General } & \multicolumn{2}{|c|}{ Material security } & \multicolumn{2}{|c|}{ Health status } & \multirow{2}{*}{$\begin{array}{l}\text { Employ- } \\
\text { ment and } \\
\text { education } \\
\text { Rating }\end{array}$} & \multicolumn{3}{|c|}{ Favourable environment } \\
\hline & Rating & Value & Rating & Value & Rating & Value & & Value & Rating & Value \\
\hline Czech Republic & 22 & 65.6 & 12 & 81.8 & 47 & 56.1 & 17 & 54.4 & 50 & 65.8 \\
\hline Estonia & 23 & 64.9 & 44 & 70.7 & 55 & 50.0 & 6 & 64.8 & 39 & 68.1 \\
\hline Slovenia & 26 & 60.6 & 25 & 77.7 & 38 & 63.2 & 79 & 23.9 & 7 & 79.2 \\
\hline Georgia & 29 & 58.8 & 48 & 66.4 & 60 & 46.2 & 19 & 53.9 & 45 & 67.1 \\
\hline Poland & 32 & 57.4 & 26 & 77.6 & 48 & 55.3 & 52 & 31.1 & 37 & 69.2 \\
\hline Latvia & 35 & 55.2 & 34 & 74.5 & 66 & 44.1 & 15 & 57.0 & 68 & 60.1 \\
\hline Hungary & 39 & 52.2 & 38 & 73.2 & 57 & 47.4 & 41 & 35.8 & 60 & 63.1 \\
\hline Slovakia & 40 & 52.1 & 21 & 78.7 & 53 & 28.2 & 28 & 45.6 & 80 & 58.5 \\
\hline Romania & 45 & 50.8 & 22 & 78.4 & 64 & 44.9 & 46 & 34.1 & 64 & 62.0 \\
\hline Bulgaria & 49 & 49.7 & 46 & 67.9 & 68 & 40.0 & 27 & 47.5 & 69 & 59.8 \\
\hline Croatia & 61 & 44.0 & 67 & 50.5 & 49 & 55.3 & 56 & 30.0 & 72 & 58.9 \\
\hline Lithuania & 63 & 43.2 & 53 & 63.8 & 65 & 44.2 & 21 & 50.0 & 90 & 52.6 \\
\hline Serbia & 66 & 41.7 & 49 & 65.8 & 62 & 45.3 & 80 & 21 & 67 & 60.2 \\
\hline Montenegro & 68 & 39.7 & 61 & 56.3 & 56 & 49.1 & 82 & 20.6 & 70 & 58.9 \\
\hline Ukraine & 73 & 37.0 & 42 & 70.9 & 85 & 27.3 & 44 & 34.8 & 85 & 54.8 \\
\hline
\end{tabular}

Source: Global AgeWatch Index, 2015

Table 3

Pensions and salaries in Ukraine, Poland and Germany in 2020

\begin{tabular}{|l|c|c|c|}
\hline \multicolumn{1}{|c|}{ Indicators } & Ukraine & Poland & Germany \\
\cline { 2 - 4 } & 2020 & 2020 & 2020 \\
\hline Minimum pension, EUR & 51.6 & 242.8 & 512 \\
\hline Minimum wage, EUR & 145 & 540.9 & 1584 \\
\hline Average pension, EUR & 102.4 & 463.63 & 1535.55 \\
\hline Average salary, EUR & 317.8 & 1015.57 & 4035 \\
\hline The ratio of the minimum pension and the minimum wage, \% & 35.6 & 44.9 & 32.3 \\
\hline The ratio of the minimum pension and the average wage, \% & 16.2 & 23.9 & 12.7 \\
\hline The ratio of average pension and average wage, \% & 32.2 & 45.6 & 38.1 \\
\hline
\end{tabular}

Source: State Statistics Service, Pension Fund of Ukraine, World Bank Representation in Ukraine, EU Statistical Office

was 4.7 times lower than in Poland and 9.9 times lower than in Germany. If we estimate the average pension, the ratio between Ukraine and Poland remains the same as the minimum pension - 4 times, and compared to Germany, this figure is significantly lower. The indicator that characterizes the level of replacement of the average wage is noteworthy. Thus, in Germany the average pension is $38.1 \%$ of the average salary in the country, while in Poland and Ukraine it is equal to $32.2 \%$ and $45.6 \%$, respectively. It once again characterizes that the income level of German pensioners is much higher than in Ukraine and Poland.

\section{The need to introduce compulsory funded pension insurance in Ukraine}

As part of the pension reform in Ukraine, an important systemic measure is the introduction of compulsory funded pension insurance, which forms the second level of the national pension system. According to some financiers, funded pension systems could become a "driver of the economy” (Pishchulina, Koval, Burlai, 2017). 
The accumulative level of pension provision will make it possible to diversify the sources of income when reaching retirement age, to further reduce the impact of the demographic factor on the state of the joint pension system. In addition, the practical use of the mandatory funded pension system will form a holistic national pension system, consisting of three levels, which are defined by domestic pension legislation (Law of Ukraine "About modification of some legislative acts of Ukraine concerning increase of pensions", 2017).

It is the need for simultaneous functioning of all three levels of the Ukrainian pension system that will contribute to its consistent formation as a holistic mechanism and will make it possible to use solidarity and accumulative pension programs, bring financial relations between the main subjects of the pension system to a new level.

The development of legislative documents, proposals for pension reform show that scientists, experts, relevant research institutions, international financial institutions are looking for the optimal mechanism that would promote the effective use of mandatory funded pension programmes in our country. It is important to analyse and evaluate the study of the main prerequisites for the effective implementation of mandatory funded pension insurance.

In the state pension insurance system, the mandatory funded pension system is considered to be a supplement to the joint pension system, which forms the 1st level of the domestic pension system. Characterizing the funded pension system with a certain contribution, scientists note that the results of its operation should determine three main factors:

- duration of insurance premium payments (it is necessary to start paying them as early as possible); - rate of insurance premium payments;

- investment income and operating expenses (USAID Financial Sector Transformation Project, 2018).

\section{Conclusions}

The pension systems of Eastern European countries and their reform in recent years show that in the near future, priority will be given to funded pension schemes. According to scientists, they can be the main source of increasing the pension income of their citizens. In the OECD view, consistency, adequacy and efficiency should be the guiding principles for building and implementing multi-level (mandatory and voluntary) pension systems. Public solidarity systems and private pension plans complement each other. Taken together, they are an integral part of the country's pension system.

In most countries of the world, including the above-mentioned countries, the basis of the pension system is mandatory pension insurance. The principles of pension insurance are the basis of both solidarity and accumulative pension system of citizens. This means that the amount of pensions will depend on the paidup insurance premiums. The role of pension insurance in the accumulative pension model is especially growing. Paid-up insurance premiums will be accumulated in the pension assets of private pension funds or other relevant financial institutions. Through these assets, they will be invested in various investment projects that provide investment income.

Reforming the national pension system is one of the priorities of the Government of our country. Starting the reform, we need to understand what we will come to what our pension system will be in the end. International experience shows that the optimal pension system must be adequate. That is, the pension should adequately replace a person's former salary so that after retirement he or she does not experience a serious deterioration in his or her financial situation because the main requirement for the pension system is to overcome the poverty of pensioners.

It is also important that the pension system is real. This means that society must have the financial capacity to ensure its adequacy - both today and in many years. In addition, it must be sustainable, as constant changes, unpredictability and adjustment lead to people losing confidence in their future, confidence in pension provisions and the government. And as today's realities show, the pension system must be reliable, one that can withstand challenges, including economic and demographic crises.

The introduction of a system of compulsory accumulative provision will gradually lead to an increase in the level of social protection of people of retirementage, the attraction of a powerful domestic long-term investment resources, which will increase investments in the national economy. 


\section{References:}

Constitution of Ukraine (1996). Available at: https://zakon.rada.gov.ua/laws/show/254к/96-вp\#Text Verkhovna Rada of Ukraine (09.07.2003). Pro zahalnooboviazkove derzhavne pensiine strakhuvannia: Zakon Ukrainy [On Compulsory State Pension Insurance: Law of Ukraine]. Available at: https://zakon.rada.gov.ua/laws/show/1058-15

Law of Ukraine (2017). "About modification of some legislative acts of Ukraine concerning increase of pensions” № 2148-VIII. Available at: https://zakon.rada.gov.ua/laws/show/2148-19\#Text

Mikhalkina E., \& Pysanka, S. (2013). Principles, mechanisms and effects of the modern pension system. Terra economicus, vol. 11, no. 3, part 2, pp. 54-63. Available at: https://cyberleninka.ru/article/n/ printsipy-mehanizmy-i-effekty-sovremennoy-sistemy-pensionnogo-obespecheniya

USAID Financial Sector Transformation Project (2018). Mandatory accumulative pension systems (2nd level) International experience: lessons for Ukraine.

State Statistics Service. Available at: http://www.ukrstat.gov.ua

Pension Fund of Ukraine. Available at: http://www.pfu.gov.ua

World Bank Representation in Ukraine. Available at: www.worldbank.org.ua

EU Statistical Office. Available at: http://epp.eurostat.ec.europa.eu

Pishchulina, O., Koval, O. \& Burlai, T. (2017). Finansovi, sotsialni ta pravovi aspekty pensiinoi reformy v Ukraini [Financial, social and legal aspects of pension reform in Ukraine]. Svitovyi dosvid ta ukrainski realii [World experience and Ukrainian realities]. Tsentr Razumkova [Razumkov Center]. Kyiv: Vydavnytstvo "Zapovit", 453 p.

The World Bank (2013). Reversal and Reduction, Resolution and Reform Lessons from the Financial Crisis in Europe and Central Asia to Improve Outcomes from Mandatory Private Pensions, World Bank, 2013.

Changing population age structures and sustainable development (2017). Report of the SecretaryGeneral on the United Nations, Fiftieth session of the Commission on Population and Development, 3-7 April 2017. New York: United Nations, Department of Economic and Social Affairs, 2 p. Available at: http://undocs.org/ru/E/CN.9/2017/2

When should the state pension age increase to 66 / Experts on age and employment. Available at: http//www.taen.org.uk

World Population Prospects (2015). The Revision, Key Findings and Advance Tables. New York: United Nations, Department of Economic and Social Affairs, pp. 4-7. Available at: https://esa.un.org/ unpd/wpp/publications/files/key_findings_wpp_2015.pdf

Establishing a European Pillar of Social Rights (2017). Commission Staff Working Document SWD201 final, European Commission, 26 April 2017. Available at: http://eur-lex.europa.eu/legal-content/EN/ TXT/?uri=COM:2017:0250:FIN

HelpAge International (2015). World quality of life index for older people. Analytical portal "Humanitarian technologies". Available at: http://gtmarket.ru/news/2015/09/28/7245

Global AgeWatch Index 2015: Insight report summary. Available at: https://www.ageinternational.org.uk/ Documents/Global_AgeWatch_Index_2015_HelpAge.pdf 